\title{
IOWA, U.S., COMMUNITIES BENEFIT FROM A TREE- PLANTING PROGRAM: CHARACTERISTICS OF RECENTLY PLANTED TREES
}

\author{
By J.R. Thompson', D.J. Nowak ${ }^{2}$, D.E. Crane ${ }^{2}$, and J.A. Hunkins ${ }^{1}$
}

\begin{abstract}
Since 1990, externally funded tree-planting activities have taken place in more than 350 Iowa, U.S., communities. The species diversity, survival, size, growth, carbon uptake, carbon storage, and pollution removal of 932 trees planted in 21 communities of different sizes and in different parts of Iowa were assessed by repeated measurements over a 4 -year period. The sample included 40 taxa and was dominated by crabapples (Malus spp.) and green ash (Fraxinus pennsylvanica Marsh.). Species diversity was described using the reciprocal of Simpson's index for the overall population (10.92), by community size, and by location in the state. No differences in species diversity were detected according to community size or location in the state. Overall survival rate for the trees was 91\%; no significant differences in survival rate related to community size or location were detected. Estimated carbon stored by all trees was 2,252 kg (4,954 lb), and carbon uptake was estimated to be $568 \mathrm{~kg} \mathrm{yr}^{-1}(1,250 \mathrm{lb})$. Total pollution removal by all trees was estimated at $2 \mathrm{~kg} \mathrm{yr}^{-1}(4.4 \mathrm{lb})$.

Key Words. Community forestry; tree survival; urban tree diversity; Simpson's index; carbon sequestration; urban forest sustainability.
\end{abstract}

Legislation enacted in 1989 by the state of Iowa, U.S., required investor-owned utilities to spend $1.5 \%$ to $2 \%$ of their revenues on cost-effective energy efficiency incentive programs. The legislation outlined several types of programs, including tree planting. The six existing electric and natural gas companies with service areas in Iowa all became involved in tree-planting programs for energy efficiency. From 1990 through 1997 (in 1997, the legislation was amended to remove the funding formula), several utilities participated in tree planting through a community challenge grant program administered by the nonprofit organization Trees Forever.

As McPherson and Simpson (1999) have indicated, many municipal shade tree programs have been supported by partnerships among utilities, nonprofit organizations, and local municipalities. Most of these programs operate at the level of a single municipality. A well-known example is Sacramento's Cool Community Program (described by Sarkovich 2003). However, in Iowa, utility-supported tree planting was coordinated at the state level by a single nonprofit organization.
By 1995, more than 350 communities throughout Iowa were involved in tree-planting programs funded by utilities in partnership with Trees Forever (Trees Forever 1995). Tree-planting activities were conducted by volunteers in most communities, and Trees Forever staff provided technical assistance and volunteer coordination in participating communities. Community volunteers were encouraged to obtain landscape-sized trees from local nurseries and were provided information on stock selection from a variety of sources (Vitosh and Thompson 2000). Participating communities were required to provide a 50:50 match for grant funds.

Benefits to communities from tree-planting programs include both social and ecological/environmental components. Social benefits include volunteer involvement, sense of community, and development of support for environmental programs such as tree planting. Ecological and environmental benefits of trees in urban and community landscapes depend on a number of factors, including their placement with respect to other structures, site conditions and tree adaptability to those conditions, rate of survivorship, age/ size of trees, tree life span, growth rate, and canopy characteristics. For example, in view of global climate change, the potential for direct benefits from carbon storage by urban trees and landscapes has been examined (Minnesota Department of Natural Resources 1991; Sampson et al. 1992; Nowak 1993, 1994; Jo and McPherson 1995; McPherson and Simpson 1999; Nowak and Crane 2002; Nowak et al. 2002), as has the potential for indirect benefits from decreased energy use made possible by proper placement of trees (Heisler 1986; Akbari et al. 1990; McPherson 1994; McPherson and Simpson 1995). These ecological functions depend heavily on the factors listed above and have gone largely unstudied in terms of benefits accruing to small towns through community forestry activities. In addition, given external support for tree planting from utility sponsors, it is important to document the contribution of new trees with respect to benefits provided (in this case, carbon storage and pollution absorption).

Community forestry in Iowa must necessarily focus on programs that will work for small communities, since 97\% of the state's incorporated places have populations of fewer than 10,000 people (Iowa League of Municipalities 1995; 
Vitosh 1998). Numerous small communities present unique difficulties and opportunities for community tree management efforts across the state and have led to a focus on leveraging resources and involving volunteers in many aspects of community forestry (as recommended for Illinois communities by Groninger et al. 2002). When volunteers are a significant component of community forestry activities, requiring a local "investment" (e.g., 50:50 match) and incorporating sound management goals (including appropriate species diversity, developing uneven-aged stands of long-lived species, providing follow-up care for newly planted trees), constant encouragement, education, and collaborative efforts among resource professionals, communities, and volunteers are necessary.

Between 1990 and 1997, a large number of young trees were added to Iowa's communities through the utilitysponsored challenge grant tree-planting program. Based on detailed project planting records, communities involved in this program planted 38 to $63 \mathrm{~mm}$ ( 1.5 to $2.5 \mathrm{in}$.) diameter balled and burlapped (44\% of trees included in the study) or 1.8 to $3.6 \mathrm{~m}$ ( 6 to $12 \mathrm{ft}$ ) containerized stock (54\% of trees) readily available at local nurseries. Three communities included in the study had access to a tree spade and planted some larger stock (2\% of trees). Community volunteers received training in tree selection, proper tree planting, and young tree maintenance from a Trees Forever community coordinator, and/or through other programs in the state (e.g., the Community Tree Steward program offered through Iowa State University Cooperative Extension). Communities were required to indicate parties responsible for performing routine maintenance at the time of planting and to provide evidence of tree maintenance for at least 3 years following planting, in order to receive subsequent grants.

Based on a community volunteer survey conducted in 1996, a conservative estimate is that approximately 18,320 trees per year were planted with support from this program in participating communities over the 3-year period 1994-1996 (Vitosh and Thompson 2000). The survey conducted in 1996 also documented changes in community programs in response to the availability of external funding and program administration by Trees Forever (Vitosh and Thompson 2000).

The 1996 survey provided the backdrop for an analysis of the biological impact of tree planting in Iowa across a wide range of community sizes and soil conditions. To help provide information to sustain Iowa's urban forest resource (e.g., Clark et al. 1997; Dwyer et al. 2003), an assessment of the newly planted trees was conducted. The objectives of this study were to measure survival, diversity, and growth rates of trees planted using external funding and to determine if community size and/or location in the state had a significant effect on tree success. An additional objective was to assess benefits provided to communities in terms of new tree functions (carbon sequestration, storage, and pollution removal).

\section{METHODS}

To obtain a representative sample of communities with newly planted trees in Iowa, a stratified random sampling scheme was used to identify 20 communities of differing sizes that had participated in utility-funded tree planting. Community selection was evenly distributed among four quadrants of the state (Table 1). Each quadrant differed in factors that influence woody plant survival and growth, primarily mean annual temperature and precipitation. The communities sampled in each quadrant included one large community (population $>10,000$ ), two medium (population 2,000-10,000), and two small communities (population $<2,000)$. One additional large community that participated in a Small Business Association-supported planting program was also selected in the second year of the study.

A random cluster sampling technique was used to identify project sites and trees within sites, based on planting records provided by community volunteers or by Trees Forever personnel. Varying proportions of trees planted on project sites in public settings (10\% to $20 \%$ ) were selected based on the total number of project sites and on the total number of trees that had been planted in each community.

Table 1. Communities in Iowa where trees were sampled by location (quadrant) and by community population level. The total number of sample trees in each community is indicated parenthetically following the community name. In all communities, trees sampled were located in public spaces, except for West Okoboji, where residential trees were evaluated.

\begin{tabular}{lllll}
\hline $\begin{array}{l}\text { Community } \\
\text { population category }\end{array}$ & Northeast & Northwest & Southeast & Southwest \\
\cline { 2 - 5 }$>10,000$ & Waterloo (58) & Sioux City (57) & Iowa City (36) & $\begin{array}{l}\text { Ankeny (46) } \\
\text { Des Moines (141) } \\
\text { Johnston (48) }\end{array}$ \\
& Maquoketa (35) & Webster City (57) & Pella (46) & Clarinda (61) \\
& Eldora (70) & Rock Valley (50) & North Liberty (57) & Lenox (22) \\
& Calmar (25) & West Okoboji (27) & Delta (14) & Treynor (10) \\
\hline
\end{tabular}


The most recent planting projects within communities were chosen - those planted during or after fall 1995. Most trees included in the sample had thus been through only the first growing season before their first measurement (an exception is described later). Repeated measurements of the same individual trees were made each year, from spring 1997 through spring 2000. Presence (survival since record or previous year), species, height, diameter [dbh, measured at $1.4 \mathrm{~m}(4.5 \mathrm{ft})]$, canopy width, and canopy shape were recorded in 1997. In addition to these parameters, foliage condition ratings and percentage of foliage retained within the measured crown volume were recorded in 1998-2000. Additional planting projects that occurred in the selected communities in spring 1997 were added to the sample in 1998. Sample tree location within the community (street, park, or school planting) was also recorded. Planting projects in the 21 st community, added in 1998, had been undertaken in 1994. Although these plantings were 4 years old at first measurement, detailed planting records were available that allowed our first measurement to include mortality since planting.

Simpson's index was calculated for the whole sample population and within each community to evaluate species diversity (Magurran 1988). The Simpson's index (D) was used because of its sensitivity to dominance (in this application, to the number of individuals of particular species or genus groups) within a test population, based on the following equation:

$$
\mathrm{D}=\Sigma\left[n_{i}\left(n_{i}-1\right)\right] /[\mathrm{N}(\mathrm{N}-1)]
$$

where $n_{i}=$ the number of specimens of the $i$ th species, and $\mathrm{N}=$ the total number of specimens in the population. The reciprocal form of Simpson's index, 1/D, increases with increasing diversity and is the value reported and used in statistical analyses. Simpson's index was selected to describe species diversity due to the known preponderance of two species in the sample.

To compare diversity, the general linear models procedure of the Statistical Analysis System was used for analysis of variance using quadrant and community size as main effects in the model (SAS Institute, Inc. 1996). Statistical significance was determined for comparisons with $\mathrm{p}<0.05$.

Survival was determined based on presence or absence of each tree based on planting records, presence in 1997, and presence in subsequent years. A logistic regression procedure of SAS was used to evaluate overall survival and survival for two species represented in all communities by location (quadrant) and community size. Williams' method was used to account for overdispersion in the analysis of overall survival. The Wald chi-square test was used in the logistic regressions to test significance at $\mathrm{p}<0.05$ (SAS Institute, Inc. 1996).
The Urban Forest Effects (UFORE) model was used to estimate carbon sequestration and pollution removal for the measured trees based on 1998 field data and 2000 hourly pollution and weather data (e.g., Nowak et al. 1998; Nowak and Crane 2000, 2002; Nowak et al. 2002). Estimates of carbon storage per tree were calculated from species and genera-specific allometric equations based on measured tree dbh and height, along with a measured adjustment factor to compensate for differences in biomass between forest and street trees (Nowak 1994). Annual sequestration estimates were based on estimated annual growth using dbh-specific growth rates from street trees (Nowak 1994) in conjunction with the allometric equations.

Hourly pollution removal was calculated using data from visual assessments of canopy density, canopy shape, and tree leaf area estimates (Nowak 1996) in conjunction with hourly weather data (for year 2000) from Des Moines and pollution concentration data (also year 2000) from throughout Iowa. These data were combined in the UFORE deposition model, which is a hybrid of big-leaf and multi-layer canopy deposition models (Baldocchi et al. 1987; Baldocchi 1988) to calculate hourly and annual pollution removal by trees.

\section{RESULTS}

In 1997, 650 trees were measured in 20 communities (Table 1). In 1998-2000, a total of 932 trees (including the previous 650) in 21 communities were evaluated [ $8 \%$ of the 268 communities that maintained volunteer tree organization records with Trees Forever as of 1996 (Vitosh and Thompson 2000)]. Based on an estimate of 18,320 trees planted per year in Iowa communities (as reported by community volunteers) between 1994 and 1996 (Vitosh and Thompson 2000), the 932 trees represent $0.7 \%$ of the approximately 130,000 trees planted between 1990 and 1997. Based on 1998 data, 39\% of trees measured were on public school properties, 23\% were street trees, and 38\% were park trees.

The number of sample trees from each community was related to community size, with means of 21,53 , and 68 trees for small, medium, and large communities, respectively. (Table 1). These numbers were proportional to the number of projects and the number of trees planted within projects according to community planting records. Number of sample trees per community ranged from 6 trees in the smallest community to 140 trees in the largest. Sampled trees were relatively evenly distributed across the four quadrants of the state, with $24 \%$ in each of the northern quadrants, $17 \%$ in the southeast, and 35\% in the southwest quadrant.

\section{Species Diversity}

Sample trees included a total of 40 taxa, with trees being identified only to genus for Malus, Prunus, and Pyrus (Table 2). The value of the reciprocal of Simpson's index for the 
overall population was 10.92 . The average value of the reciprocal of Simpson's index for the quadrants ranged from 4.93 for the southeast to 7.12 for the southwest, although there were no significant differences among quadrants (Table 3). The values of the reciprocal of Simpson's index for individual communities ranged from 1.50 to 13.48 , although no significant differences were detected among means calculated for community size (Table 3 ).

The 10 most commonly planted taxa, which represented approximately $70 \%$ of the sample, were crabapple (Malus spp.), green ash (Fraxinus pennsylvanica Marsh.), red maple (Acer rubrum L.), sugar maple (A. saccharum Marsh.), basswood (Tilia americana L.), Norway maple (A. platanoides L.), honeylocust (Gleditsia triacanthos L. var inermis Willd.), northern red oak (Quercus rubra L.), Japanese tree lilac (Syringa reticulata), and ornamental pear (Pyrus calleryana).

\section{Survival}

Based on final field assessments in spring 2000, 847 of 932 trees were still alive, for an overall survival rate of $91 \%$ (for most trees, this was over the first 3 or 4 years after planting). Average annual mortality rates, based on tree presence/ absence in each year subsequent to first measurement, were 6\%. Survival rates for all species combined ranged from $88 \%$ to $94 \%$ among quadrants, from $88 \%$ to $92 \%$ by community size (Table 3 ) and from $87 \%$ to $93 \%$ by project site (street, park, or school). Based on logistic regressions using Wald's chisquare test, there were no significant differences in overall survival due to quadrant, community size, or project site location.

Survival rates for the 10 most common species ranged from $73 \%$ for red maple and basswood to $100 \%$ for tree lilac (Table 4). No significant differences were found for crabapple or green ash survival rates when compared by quadrant and community size using the logistic regression procedure. Other than crabapple and green ash, survival rates for individual taxa were not compared statistically due to incomplete representation among communities and quadrants.
Table 2. Taxa represented in the sample of new community trees in Iowa, number of specimens of each, and communities in which they were part of the sample. Malus spp. and Fraxinus pennsylvanica were the only taxa sampled in all communities.

\begin{tabular}{|c|c|c|}
\hline Species (group) & $\begin{array}{l}\text { Number of } \\
\text { trees in } 1998 \\
\end{array}$ & $\begin{array}{l}\text { Number of communities } \\
\text { species was sampled in }\end{array}$ \\
\hline Abies concolor Lindl. & 10 & 1 \\
\hline Acer $\times$ freemannii & 12 & 4 \\
\hline Acer tataricum L. subsp. ginnala Maxim. & 8 & 2 \\
\hline Acer nigrum Michx. & 7 & 3 \\
\hline Acer platanoides L. & 36 & 10 \\
\hline Acer rubrum L. & 47 & 10 \\
\hline Acer saccharinum L. & 9 & 7 \\
\hline Acer saccharum Marsh. & 46 & 11 \\
\hline Amelanchier arborea Michx. & 7 & 2 \\
\hline Betula nigra L. & 20 & 5 \\
\hline Celtis occidentalis L. & 22 & 5 \\
\hline Cercis canadensis L. & 8 & 2 \\
\hline Craetagus phaenopyrum L. & 17 & 5 \\
\hline Cornus florida L. & 3 & 1 \\
\hline Fraxinus americana L. & 17 & 4 \\
\hline Fraxinus pennsylvanica Marsh. & 107 & 21 \\
\hline Gingko biloba L. & 2 & 2 \\
\hline Gleditsia triacanthos L. var inermis Willd. & 33 & 7 \\
\hline Gymnocladus dioicus L. & 1 & 1 \\
\hline Koelreuteria paniculata & 1 & 1 \\
\hline Malus spp. & 215 & 21 \\
\hline Picea glauca Moench & 16 & 5 \\
\hline Picea mariana Mill. & 12 & 1 \\
\hline Picea pungens Englm. & 2 & 2 \\
\hline Pinus strobus L. & 5 & 1 \\
\hline Pinus sylvestris L. & 24 & 2 \\
\hline Populus alba $\times$ P. grandidentata & 8 & 1 \\
\hline Prunus spp. & 12 & 5 \\
\hline Pyrus spp. & 25 & 5 \\
\hline Quercus alba L. & 2 & 2 \\
\hline Quercus bicolor Willd. & 8 & 3 \\
\hline Quercus macrocarpa Michx. & 11 & 9 \\
\hline Quercus palustris Muenchh. & 8 & 4 \\
\hline Quercus rubra L. & 30 & 10 \\
\hline Salix babylonica L. & 1 & 1 \\
\hline Syringa reticulata & 27 & 5 \\
\hline Thuja occidentalis L. & 9 & 2 \\
\hline Tilia americana L. & 49 & 10 \\
\hline Tilia cordata Mill. & 4 & 3 \\
\hline Ulmus americana cv. Liberty & 1 & 1 \\
\hline
\end{tabular}


Table 3. Values of the reciprocal of Simpson's Diversity Index (SDI) and tree survival, for each community (one large, two medium, and two small communities) and by quadrant. Standard errors for marginal means of Simpson's index are included. No significant differences were detected for either diversity or survival between quadrants or by community size.

\begin{tabular}{|c|c|c|c|c|c|c|c|}
\hline \multirow{2}{*}{$\begin{array}{l}\text { Community } \\
\text { population category }\end{array}$} & & \multicolumn{4}{|c|}{ Quadrant } & \multirow{2}{*}{$\begin{array}{l}\text { Average for } \\
\text { community size }\end{array}$} & \multirow{2}{*}{$\begin{array}{l}\text { Standard error of } \\
\text { marginal mean (SDI) }\end{array}$} \\
\hline & & $\overline{\mathrm{NE}}$ & NW & SE & SW & & \\
\hline \multirow[t]{2}{*}{$>10,000$} & Diversity & 7.06 & 8.14 & 2.68 & $\begin{array}{l}3.81 \\
6.94^{*}\end{array}$ & 5.81 & 1.53 \\
\hline & Survival (\%) & 84 & 84 & 94 & $\begin{array}{l}89 \\
98^{*}\end{array}$ & 92 & \\
\hline \multirow[t]{2}{*}{$2,000-10,000$} & Diversity & $\begin{array}{l}12.42 \\
5.16\end{array}$ & $\begin{array}{l}2.69 \\
3.83\end{array}$ & $\begin{array}{l}6.75 \\
6.84\end{array}$ & $\begin{array}{l}6.79 \\
13.48\end{array}$ & 7.24 & 1.16 \\
\hline & Survival (\%) & $\begin{array}{l}91 \\
87\end{array}$ & $\begin{array}{l}91 \\
90\end{array}$ & $\begin{array}{l}100 \\
87\end{array}$ & $\begin{array}{l}98 \\
92\end{array}$ & (2) & \\
\hline \multirow[t]{2}{*}{$<2,000$} & Diversity & $\begin{array}{l}4.08 \\
6.88\end{array}$ & $\begin{array}{l}4.76 \\
2.46\end{array}$ & $\begin{array}{l}9.10 \\
1.50\end{array}$ & $\begin{array}{l}7.70 \\
4.00\end{array}$ & 5.06 & 1.16 \\
\hline & Survival (\%) & $\begin{array}{l}92 \\
94\end{array}$ & $\begin{array}{l}89 \\
85\end{array}$ & $\begin{array}{l}100 \\
100\end{array}$ & $\begin{array}{l}59 \\
90\end{array}$ & 88 & \\
\hline $\begin{array}{l}\text { Average } \\
\text { for quadrant }\end{array}$ & $\begin{array}{l}\text { Diversity } \\
\text { Survival (\%) }\end{array}$ & $\begin{array}{l}7.11 \\
89\end{array}$ & $\begin{array}{l}5.00 \\
88\end{array}$ & $\begin{array}{l}4.93 \\
94\end{array}$ & $\begin{array}{l}7.12 \\
93\end{array}$ & & \\
\hline Standard error of SD & marginal mean & 1.54 & 1.54 & 1.54 & 1.34 & & \\
\hline
\end{tabular}

"Two large communities were sampled in the southwest quadrant.

Table 4. Percentage of sample population represented by the ten most common taxa, their individual survival rates, and mean height, diameter, and crown width with related standard errors as measured in spring 2000. Together these taxa make up approximately $70 \%$ of the sample population.

\begin{tabular}{|c|c|c|c|c|c|}
\hline Taxa & $\%$ of population & $\%$ survival & Height, m (S.E.) & Diameter, mm (S.E.) & Crown, m (S.E.) \\
\hline Crabapple & 24 & 91 & $3.6(0.6)$ & $56(19)$ & $2.8(0.7)$ \\
\hline Green ash & 12 & 88 & $5.6(1.2)$ & $83(31)$ & $3.2(0.9)$ \\
\hline Red maple & 5 & 73 & $4.8(1.3)$ & $60(14)$ & $2.3(0.6)$ \\
\hline Sugar maple & 5 & 78 & $5.1(1.4)$ & $65(32)$ & $2.4(0.9)$ \\
\hline Basswood & 5 & 73 & $4.8(0.9)$ & $80(15)$ & $2.8(0.6)$ \\
\hline Norway maple & 4 & 89 & $5.1(1.0)$ & $78(24)$ & $2.9(0.9)$ \\
\hline Honeylocust & 4 & 88 & $5.3(0.6)$ & $79(9)$ & $4.1(0.8)$ \\
\hline Red oak & 3 & 88 & $4.5(1.2)$ & $60(17)$ & $2.7(0.6)$ \\
\hline Japanese tree lilac & 3 & 100 & $2.8(0.5)$ & $41(15)$ & $1.5(0.2)$ \\
\hline Ornamental pear & 3 & 78 & $5.0(1.1)$ & $78(18)$ & $2.9(0.9)$ \\
\hline
\end{tabular}

on variation in post-transplant growth rates. The average size of trees in spring 2000 compared to the year of first measurements indicated overall annual growth rates of 8 $\mathrm{mm} \mathrm{yr}^{-1}(0.31 \mathrm{in})$ in diameter, $0.29 \mathrm{~m} \mathrm{yr}^{-1}$ height $(0.95 \mathrm{ft})$, and $0.30 \mathrm{~m} \mathrm{yr}^{-1}(0.98 \mathrm{ft})$ in canopy spread (Table 5$)$.

\section{Carbon Storage}

Tree size and condition data collected in 1998 for 857 trees [out of 879 surviving trees, 22 trees that were less than 1.3 $\mathrm{cm}(0.5 \mathrm{in}$.) diameter were not included in the analysis because the model is designed for trees with a minimum dbh of $1.3 \mathrm{~cm}$ ] were used in the UFORE model to estimate carbon (C) storage and annual sequestration on an individual tree basis. Total $\mathrm{C}$ stored by the population of trees was estimated at 2,252 kg (4,954 lb), or about $2.7 \mathrm{~kg}(5.9$ lb) per tree. Total $C$ sequestration was estimated at $568 \mathrm{~kg}$ $\mathrm{yr}^{-1}(1,250 \mathrm{lb})$ or about $0.68 \mathrm{~kg} \mathrm{yr}^{-1}(1.5 \mathrm{lb})$ per tree. C storage and sequestration rates varied according to tree size and species. 
Table 5. Ranges and averages for incremental height and diameter growth rates for recently planted trees measured in Iowa and growth rates reported in the literature (sources noted as footnotes below table) for young trees.

\begin{tabular}{llllll}
\hline & \multicolumn{2}{c}{ Height $\left(\mathrm{cm} \mathrm{yr}^{-1}\right)$} & & \multicolumn{2}{c}{ Diameter $\left(\mathrm{mm} \mathrm{yr}^{-1}\right)$} \\
\cline { 2 - 3 } \cline { 5 - 6 } & Range & Average & & Range & Average \\
\hline Measured in Iowa & $17-53$ & 29 & & $5.0-13.0$ & 8.0 \\
Published & $5-60^{z}$ & 27 & & $3.8-16.0^{y}$ & 7.9 \\
\hline
\end{tabular}

${ }^{2}$ Includes data for shoot extension from Kjelgren and Clark 1992 (sweetgum trees in Seattle); Rhoads et al. 1981 (several species in Philadelphia); and Buckstrup and Bassuk 2000 (hackberry, hophornbeam, and swamp white oak in Ithaca, New York), and estimates for height growth of young trees from Frelich 1992 (12 species, Minneapolis).

yIncludes data from Neal and Whitlow 1997 (willow oak in Washington, D.C.); Rhoades and Stipes 1999 (nine different species in Virginia); Kjelgren and Clark 1992 (as above); Frelich 1992 (as above), Jo and McPherson 1995 (several young hardwood species in Chicago); and Nowak et al. 1990 (black locust, southern magnolia, and London plane tree in California).

\section{Air Pollution Removal}

Air pollution removal by the 879 surviving trees in 1998 was estimated at $21.2 \mathrm{~kg} \mathrm{yr}^{-1}(46.6 \mathrm{lb})$, with an annual value of US $\$ 117.30$ per year (Table 5). The greatest removal was for ozone and particulate matter less than 10 microns.

\section{DISCUSSION}

The results of this assessment indicate the success of this externally funded program in planting and sustaining new trees as a part of community forestry, implemented largely by volunteers, and effective even for small towns. Earlier research also indicated that the methods used in utility grant administration by Trees Forever contributed to broad community support for tree-related activities and a more comprehensive approach to vegetation management (Vitosh and Thompson 2000), also essential to community forest sustainability (Clark et al. 1997; Dwyer et al. 2003).

Diversity indices have not frequently been used in urban tree analyses; more often, results have been described and recommendations have been made based on proportional representation of different species in a population (e.g., Barker 1975; Miller and Miller 1991). For this study, examining species diversity for the whole population of trees added to Iowa communities, as well as comparison of diversity in populations according to community size and quadrant, was facilitated by the use of Simpson's index. Our estimates of diversity are conservative, due to inclusion of Malus, Prunus, and Pyrus as genus groups (this decision was made to simplify field operations and other data analyses, because species and cultivars within these groups are functionally similar). In most communities, a single species from these groups was most readily available at the local nursery, and plantings within these genera were very uniform.

For a hypothetical population of 1,000 trees, with 100 each of 10 species (following the recommendation of no more than 10\% representation by individual species proposed by Miller and Miller 1991), the reciprocal of Simpson's index would be 10.10. For a population of 1,000 trees with 400 individuals of a single species, 100 each of 5 species, and 25 each of 4 additional species, the reciprocal of Simpson's index would be 4.72 (same total number of species with unequal representation). For a natural forest area in the central hardwoods region (Missouri), Magurran (1988) calculated a value of 5.36. Most of the values calculated for new trees in the communities assessed were between the hypothetical values offered above, and many were greater than that for the natural forest (indicative of range of diversity of native and therefore well-adapted species in the area). Although there appeared to be heavy reliance on a few taxa (particularly the crabapples and green ash), species diversity for the population as a whole (10.92) was greater than the hypothetical value for balanced representation of 10 species.

Although we expected diversity to be greater in the southeastern portion of the state (due to a greater variety of well-adapted indigenous species) and in larger communities (due to likelihood of a greater selection in local nurseries), no significant differences in diversity were detected according to community size or location (Table 3). Anecdotally, volunteer contacts in the two communities with relatively high diversity indices (12.42 and 13.48) identified species diversity as a priority in their planting program. Although green ash is already a significant component of Iowa's community forests, most other species that were relatively common in planting projects examined in this study are not over-represented among mature tree populations (Iowa Department of Natural Resources 1996). It is important to balance the priority of having diversity in species representation with the need to select species that are well adapted to the site and growing conditions (e.g., Richards 1993). The data indicate that overall diversity of this new population of trees is greater than that of local forests, and also greater than what would be expected following the $10 \%$ rule, but long-term observations will be necessary to adequately assess each species' performance, especially for species that are not already well represented in mature community tree populations.

Overall survival (91\%) for this population of new trees was higher than indicated in many previous reports for other community tree-planting projects and programs, although rates that have been reported are extremely variable depending on the nature of the setting and the species of trees. For example, Nowak et al. (1990) reported first-year survival of $82 \%$ and second-year survival of $66 \%$ for newly planted street trees in California. Mortality rates in the California study differed significantly by adjacent land 
use type. Based on their survey of the literature, an average first-year mortality rate of $16 \%$ could be expected, although the range was from 3\% to 99\%. Again, average annual mortality over 3 or 4 years for the trees in this study was only $6 \%$ and did not vary significantly by setting (community size, location in the state, or site type).

In a study of street trees in three Wisconsin cities, Miller and Miller (1991) reported survival rates from 52\% to $76 \%$ over 4 years. In our study, we anticipated higher survival rates in larger communities (often with professional tree care staff) and in the southern portion of the state (milder climatic conditions). However, survival rates in this study were uniformly high and no significant differences were detected according to community size or location. One community with a small number of trees had a relatively low survival rate (59\%), probably due to poor site conditions at a single planting project where most of the trees were located. Postmortem observations, although not recorded in every instance, indicated that street trees and park trees often had been damaged by mowers or occasionally had been planted too deep. School trees and street trees were damaged by construction activities and subsequently died in a few cases. In parks located on the periphery of small towns, deer rub appeared to have been an important factor in tree mortality.

Average incremental height and diameter growth rates for trees in this study compare favorably with those reported in the literature for recently transplanted trees (Table 5). Comparison data are taken from a variety of studies that focused on only one or a few sites, and in locations from throughout the United States. We were unable to find documentation for similar externally supported treeplanting programs coordinated at the scale of an entire state for comparison. Survival rates for individual taxa also varied in this study, although statistical analysis was precluded by the limited number of trees (for most species) and their uneven distribution across the state.

Tree size information also was included in this report to establish a frame of reference for the carbon uptake and carbon sequestration performance of the trees. As of yet, these trees do not store a significant amount of carbon (an estimated total of 2,252 kg). McPherson and Simpson (1999) and Nowak et al. (2002) have noted that performance of community trees as carbon sinks increases as trees mature and net carbon effects are greater for long-lived, low-maintenance trees that are large at maturity. In fact, net carbon storage by community trees can be diminished by the carbon emissions that are required for maintenance (Jo and McPherson 1995; Nowak et al. 2002). The ornamental species (crabapple, pear, and tree lilac) that were abundant in this study probably will not contribute significantly to carbon storage due to their relatively small stature at maturity. However, a number of the other species (approximately
$40 \%$ of the taxa) that were also commonly planted will mature to be medium- to large-sized trees, and are mediumto long-lived; for example, green ash, red maple, basswood, honeylocust, and red oak (McPherson and Simpson 1999; Nowak et al. 2002). The potential certainly exists for these trees to sequester and store significant quantities of carbon over their life spans. In Chicago, Illinois, and Brooklyn, New York, average carbon storage of trees greater than $75 \mathrm{~cm}$ (30 in.) dbh were respectively 1,000 and 530 times greater than trees less than $7.5 \mathrm{~cm}$ (3 in.) dbh (Nowak 1994; Nowak et al. 2002). The relatively large difference for carbon storage between Chicago and Brooklyn was related to the difference in diameter distribution of trees greater than 75 $\mathrm{cm}$ dbh.

The trees in Iowa currently remove about $21 \mathrm{~kg}(46.2 \mathrm{lb})$ of air pollution annually (Table 6 ). This amount equates to about $24 \mathrm{~g}(0.84 \mathrm{oz})$ per tree per year. This removal rate is comparable to small trees in Chicago and Brooklyn (Nowak 1994; Nowak et al. 2002). The standardized removal rate for these trees (grams of pollution removed per meter square of canopy) was about 6.2. This removal rate is relatively low compared to other cities (e.g., Brooklyn, 10.2 $\mathrm{g} / \mathrm{m}^{2}$; Chicago, $8.9 \mathrm{~g} / \mathrm{m}^{2}$ ) likely due to the relatively low leaf area index of these small trees, differences in local meteorology, and the relatively clean air in Iowa compared to some other areas. The amount of pollution removed by these trees will increase annually as the trees grow. Large trees greater than $75 \mathrm{~cm}$ dbh in the previously cited studies removed 67 and 65 times more pollution, respectively, than trees less than $7.5 \mathrm{~cm}$ dbh, with removal rates reaching about $2 \mathrm{~kg}(4.4 \mathrm{lb}$ ) per tree per year for large trees (Nowak 1994; Nowak et al. 2002).

Table 6. Total estimated pollution removal $\left(\mathrm{kg} \mathrm{yr}^{-1}\right)$ and associated monetary value (dollars $\mathrm{yr}^{-1}$ ) for 879 street trees in Iowa during nonprecipitation periods (dry deposition) in 2000. Monetary value of pollution removal by trees was estimated using the median externality values for the United States for each pollutant (Murray et al. 1994). Externality values for ozone were set to equal the value for $\mathrm{NO}_{2}$.

\begin{tabular}{lll}
\hline Pollutant & Removal $\left(\mathrm{kg} \mathrm{yr}^{-1}\right)$ & Value $\left(\mathrm{USS} \mathrm{yr}^{-1}\right)$ \\
\hline Ozone & 10.2 & 68.6 \\
Particulate matter $<10 \mu^{\mathrm{z}}$ & 6.4 & 28.8 \\
Nitrogen dioxide $^{\mathrm{y}}$ & 2.5 & 16.7 \\
Sulfur dioxide & 1.7 & 2.8 \\
Carbon monoxide & 0.4 & 0.4 \\
Total & $\mathbf{2 1 . 2}$ & $\mathbf{1 1 7 . 3}$ \\
\hline
\end{tabular}

${ }^{z}$ Assumes $50 \%$ re-suspension of particles.

yecause there was no complete data set on nitrogen dioxide $\left(\mathrm{NO}_{2}\right)$ concentrations in Iowa, estimates of $\mathrm{NO}_{2}$ removal by trees in Iowa were based on removal rates for trees in Omaha, Nebraska in $1994\left(0.73 \mathrm{~g} / \mathrm{m}^{2}\right.$ of canopy cover). This estimate is reasonable due to geographical proximity of Omaha to Iowa; also, removal rates in Omaha were relatively low compared to data from other cities in the United States. 


\section{CONCLUSIONS}

Results of the survey conducted in 1996 indicated that the guidance provided to communities along with utility grant funding that supported tree-planting efforts in Iowa communities were effective in developing social support for community tree-related activities (Vitosh and Thompson 2000). Findings of this study point also to the effectiveness of the program in terms of the diversity of trees added to Iowa communities, excellent survival, and favorable growth rates of the newly planted trees, and the potential for future growth and environmental benefits that will accrue. Planting and maintenance efforts directed toward this new population of trees have been largely in the hands of volunteers who received assistance and education from Trees Forever staff, as well as the Iowa Urban and Community Forestry Council, Iowa State University Cooperative Extension personnel, Iowa Department of Natural Resources staff, and local nurseries (Vitosh and Thompson 2000). Volunteer activities have contributed to an enhanced vegetation resource in communities throughout Iowa. Quantification of the ecological and environmental functions of these trees provides important information to utility sponsors about current and anticipated benefits of large-scale tree-planting programs.

\section{LITERATURE CITED}

Akbari, H., A. Rosenfeld, and H. Taha. 1990. Summer heat islands, urban trees, and white surfaces. ASHRAE Trans. 96:1381-1388.

Baldocchi, D. 1988. A multi-layer model for estimating sulfur dioxide deposition to a deciduous oak forest canopy. Atmos. Environ. 22:869-884.

Baldocchi, D., B. Hicks, and P. Camara. 1987. A copy stomatal resistance model for gaseous deposition to vegetated surfaces. Atmos. Environ. 21:91-101.

Barker, P. 1975. Ordinance control of street trees. J. Arboric. 11:212-215.

Buckstrup, M.J., and N.L. Bassuk. 2000. Transplanting success of balled-and-burlapped versus bare-root trees in the urban landscape. J. Arboric. 26(6):298-308.

Clark, J., N. Matheny, G. Cross, and V. Wake. 1997. A model of urban forest sustainability. J. Arboric. 23:17-30.

Dwyer, J.F., D.J. Nowak, and M.H. Noble. 2003. Sustaining urban forests. J. Arboric. 29(1):49-55.

Frelich, L. 1992. Predicting Dimensional Relationships for Twin Cities Shade Trees. Department of Forest Resources, University of Minnesota, St. Paul, MN 33 pp.

Groninger, J., D. Close, and C. Basman. 2002. Can small, rural communities practice urban forestry? J. For. 100(1):23-28.

Heisler, G.M. 1986. Energy savings with trees. J. Arboric. 12:113-125.

Iowa Department of Natural Resources. 1996. A Vision for Iowa's Forests 1996-2001: Forest Resources Plan of
Action. Iowa Department of Natural Resources, Des Moines, IA. 19 pp.

Iowa League of Municipalities. 1995. Cities and Populations as of June 1995. Iowa League of Municipalities, Des Moines, IA. 16 pp.

Jo, H.K., and E.G. McPherson. 1995. Carbon storage and flux in urban residential greenspace. J. Environ. Manage. 45:109-133.

Kjelgren, R.K., and J.R. Clark. 1992. Microclimates and tree growth in three urban spaces. J. Environ. Hortic. 10(3):139-145.

Magurran, A.E. 1988. Ecological Diversity and Its Measurement. Princeton University Press, Princeton, NJ.

McPherson, E.G. 1994. Using urban forests for energy efficiency and carbon storage. J. For. 92(10):36-41.

McPherson, E.G., and J.R. Simpson. 1995. Shade trees as a demand-side resource. Home Energ. 12(2):11-17.

- 1999. Carbon Dioxide Reduction Through Urban Forestry: Guidelines for Professional and Volunteer Tree Planters. Gen Tech. Rep. PSW-GTR-171, USDA Forest Service Pacific Southwest Research Station, Albany, CA.

Miller, R.H., and R.W. Miller. 1991. Planting survival of selected street tree taxa. J. Arboric. 17:185-191.

Minnesota Department of Natural Resources. 1991. Carbon Dioxide Budgets in Minnesota and Recommendations on Reducing Net Emissions with Trees. Report to the Minnesota Legislature.

Murray, F.J., L. Marsh, and P.A. Bradford. 1994. New York State Energy Plan, Vol. II: Issue Reports. New York State Energy Office, Albany, NY.

Neal, B.A., and T.H. Whitlow. 1997. Using tree growth rates to evaluate urban tree planting specifications. J. Environ. Hortic. 15(2):115-118.

Nowak, D.J. 1993. Atmospheric carbon reduction by urban trees. J. Environ. Manage. 37:207-217. . 1994. Atmospheric carbon dioxide reduction by Chicago's urban forest, Ch. 6. In McPherson, E.G., D.J. Nowak, and R.A. Rowntree (eds.). Chicago's Urban Forest Ecosystem: Results of the Chicago Urban Forest Climate Project. NE-GTR 186, USDA Forest Service, Northeastern Forest Experiment Station, Radnor, PA.

- 1996. Estimating leaf area and leaf biomass of opengrown deciduous urban trees. For. Sci. 42:504-507.

Nowak, D.J., and D.E. Crane. 2000. The Urban Forest Effects (UFORE) model: Quantifying urban forest structure and functions, pp 714-720. In Proceedings of the 2nd International Symposium on Integrated Tools for Natural Resources Inventories in the 21st Century. Gen. Tech. Rep. NC-212, USDA Forest Service, North Central Forest Experiment Station, St. Paul, MN.

- 2002. Carbon storage and sequestration by urban trees in the USA. Environ. Pollut. 116(3):381-389. 
Nowak, D.J., D.E. Crane, J.C. Stevens, and M. Ibarra. 2002. Brooklyn's Urban Forest. USDA Forest Service Gen. Tech. Rep. NE-290. 107 pp.

Nowak, D.J., J.R. McBride, and R.A. Beatty. 1990. Newly planted street tree growth and mortality. J. Arboric. 16:124-129.

Nowak, D.J., P.J. McHale, M. Ibarra, D. Crane, J. Stevens, and C. Luley. 1998. Modeling the effects of urban vegetation on air pollution, pp 399-407. In Gryning, S.E., and N. Chaumerliac (eds.). Air Pollution Modeling and Its Application XII. Plenum Press, New York, NY.

Nowak, D.J., J.C. Stevens, S.M. Sisinni, and C.J. Luley. 2002. Effects of urban tree management and species selection on atmospheric carbon dioxide. J. Arboric. 28:113-122.

Richards, N. 1993. Reasonable guidelines for street tree diversity. J. Arboric. 19:344-349.

Rhoades, R.W., and R. J. Stipes. 1999. Growth of trees on the Virginia Tech campus in response to various factors. J. Arboric. 25(4):211-215.

Rhoads, A.F., P.W. Meyer, and R. Sanfelippo. 1981. Performance of urban street trees evaluated. J. Arboric. 7(5):127-132.

Sampson, R.N., G.A. Moll, and J.J. Kielbaso, 1992. Opportunities to increase urban forests and the potential impacts on carbon storage and conservation. In Sampson, R.N., and D. Hair (eds.). Forests and Global Change: Opportunities for Increasing Forest Cover, Vol. 1. American Forests, Washington, DC.

Sarkovich, M. 2003. Shade Tree Program: Sacramento Municipal Utility District. America's Best, ACEEE. www.aceee.org/utility/7bsmudshadetree.pdf (accessed 7/30/03)

SAS Institute, Inc. 1996. SAS/STAT User's Guide, Release 6.12. Cary, NC.

Trees Forever. 1995. IES Utilities, Inc.: Branching Out Report. Trees Forever, Marion, IA.

Vitosh, M.A. 1998. General Assessment of Urban and Community Forestry Activities in Iowa 1994 to 1996. M.S. thesis, Iowa State University, Ames, IA. 53 pp.

Vitosh, M. A., and J. R. Thompson. 2000. Iowa communities benefit from an externally funded tree-planting program. J. Arboric. 29:114-119.

Acknowledgments. This journal paper of the Iowa Agriculture and Home Economics Experiment Station, Ames, Iowa, Project No. 4005, was supported by McIntire-Stennis and State of Iowa funds. The work described also was supported by a John Z. Duling Grant, administered through the TREE Fund, International Society of Arboriculture and the National Arborist Association (formerly the ISA Research Trust). We thank Trees Forever personnel and Iowa Department of Natural Resources personnel for assistance in identifying participating communities and providing data. We would like to express our appreciation to community collaborators who provided additional information and support for fieldwork. We appreciate field assistance provided by Andrew Kaufman, Roger Hanna, Richard Faltonson, Chuck Rodrigues, John Smith, Valasia Iakovoglou, Daniel Anderson, and Carol LaFaver, and assistance with statistical analyses provided by Dr. Phillip Dixon and Reid Landes.

${ }^{1 *}$ Department of Natural Resource Ecology and Management 253 Bessey Hall

Iowa State University

Ames, IA 50011, U.S.

${ }^{2}$ USDA Forest Service

Northeastern Research Station

5 Moon Library

SUNY-ESF

Syracuse, NY 13210, U.S.

"Corresponding author: J.R. Thompson 
Résumé. Depuis 1990, des activités de plantations d'arbres financées par des sources externes se sont implantées dans plus de 350 communautés de l'Iowa. La diversité en espèces, le taux de survie, la dimension, la croissance, le captage et le stockage du carbone, et le taux de dépollution produits par 932 arbres plantés au sein de 21 communautés de différents tailles et de différentes régions de l'Iowa ont été évalués au moyen de mesures répétées sur une période de quatre ans. L'échantillon inclut 40 variétés différentes d'arbres et est dominé par celles de pommetiers (Malus spp.) et de frênes de Pennsylvanie (Fraxinus pennsylvanica). La diversité en espèce a été décrite au moyen de l'index de réciprocité de Simpson pour la population entière $(10,92)$, et ce par rapport à la taille de la communauté et par rapport à sa localisation au sein de l'état. Aucune différence significative dans la diversité en espèces n'a été détectée par rapport à la taille de la communauté ou sa localisation. Le taux global moyen de survie était de 91\%; aucune différence significative dans le taux de survie par rapport à la taille de la communauté ou sa localisation n'a été détectée. La quantité de carbone emmagasiné par tous les arbres a été estimée à $2252 \mathrm{~kg}$ et la quantité de carbone capté de $568 \mathrm{~kg}$ par année. La quantité totale de polluants éliminés pour tous les arbres est estimée à $2 \mathrm{~kg}$ par année.

Zusammenfassung. Seit 1990 fanden in Iowa in mehr als 350 Kommunen extern finanzierte Baumpflanzaktionen statt. Über eine Periode von 4 Jahren wurde von 932 gepflanzten Bäumen in 21 Gemeinden in periodisch wiederkehrenden Messungen die Art, Vielfalt, Überleben, Größe, Wachstum, C-Aufnahme und -speicherung und Verschmutzung aufgenommen. Die Proben enthielten 40 Taxa und waren dominiert von Malus spp. und Fraxinus pennsylvanica. Die Diversität der Species wurde anhand des Simpson-Index für die gesamte Population (10/92), der Größe der Gemeinde und des Standorts bestimmt. In Bezug auf die Größe der Kommune oder des Standorts konnte keine Unterschiede in der Artenvielfalt entdeckt werden. Die allgemeine Überlebensrate lag bei 91\%, es gab ebenso keine signifikanten Unterschiede bei Standort und Größe der Kommune. In allen Bäumen wurde ca. $2.252 \mathrm{~kg}$ Kohlenstoff gespeichert und die jährliche Aufnahme betrug ca. $568 \mathrm{~kg}$. Die Aufnahme von Luftverschmutzung wurde mit $2 \mathrm{~kg}$ pro Jahr für alle Bäume geschätzt.

Resumen. Desde 1990 se han llevado a cabo actividades de plantación en Iowa en más de 350 comunidades. Se midió la diversidad de especies, supervivencia, tamaño, crecimiento, absorción de carbono, almacenamiento de carbono y remoción de contaminación de 932 árboles plantados en 21 comunidades de diferentes tamaños en diferentes partes de Iowa, mediante mediciones repetidas en un período de cuatro años. La muestra incluyó 40 taxa y fue dominada por manzanos (Malus spp.) y fresnos (Fraxinus pennsylvanica Marsh.). La diversidad de especies fue descrita usando el recíproco del índice de Simpson para toda la población (10.92), por tamaño de comunidad y por localización en el Estado. No se detectaron diferencias en diversidad de especies de acuerdo al tamaño de la comunidad o localización en el estado. La tasa de supervivencia para los árboles fue 91\%; no se detectó diferencias significativas en tasa de supervivencia de acuerdo al tamaño de la comunidad o localización en el estado. La estimación del carbono almacenado para todos los árboles fue 2,252 Kg. y la absorción de carbono fue estimada en $568 \mathrm{Kg}$. $\mathrm{yr}^{-1}$. La remoción de la contaminación total para todos los árboles fue estimada en $2 \mathrm{Kg}$. $\mathrm{yr}^{-1}$. 